Marie-Thérèse Berthier · Alain Houde

Ann-Marie Paradis · Patrick Couture · Daniel Gaudet

Jean-Pierre Després · Marie-Claude Vohl

\title{
Molecular screening of the microsomal triglyceride transfer protein: association between polymorphisms and both abdominal obesity and plasma apolipoprotein B concentration
}

Received: 25 June 2004/ Accepted: 22 September 2004/Published online: 10 November 2004

(C) The Japan Society of Human Genetics and Springer-Verlag 2004

\begin{abstract}
Microsomal triglyceride transfer protein (MTP) plays a critical role in the assembly of lipoproteins. The aim of this study was first to seek new MTP gene variants and then to verify whether MTP gene polymorphisms were associated with plasma lipoprotein/lipid levels in men with visceral obesity. Molecular screening of the MTP gene revealed 11 polymorphisms. The carriers of the c.933A allele and c.1151C allele or $-400 \mathrm{~A} / \mathrm{A}$ homozygotes were characterized by increased levels of abdominal visceral adipose tissue (AT) measured by computed tomography $(P=0.02, P=0.04$, $P=0.03$, respectively). After dividing each genotype group into subgroups using $130 \mathrm{~cm}^{2}$ as a cutoff point for visceral AT, significantly higher low-density lipoprotein (LDL)-apolipoprotein B (apoB) concentrations were found in obese men bearing the c. $891 \mathrm{G}$ allele, the $-400 \mathrm{~T}$ allele, as well as for $282 \mathrm{G} / \mathrm{G}$ homozygotes, 933C/C homozygotes, and $1151 \mathrm{~A} / \mathrm{A}$ homozygotes when compared to their lean counterparts. Haplotypes were not associated with phenotypes under study. In conclusion, some MTP gene polymorphisms in the French Canadian population are associated with the amount of
\end{abstract}

M.-T. Berthier $\cdot$ A. Houde $\cdot$ A.-M. Paradis

P. Couture · J.-P. Després · M.-C. Vohl $(\bowtie)$

Lipid Research Center, TR93, CHUQ Pavilion CHUL,

2705 Laurier Blvd, TR93, Sainte-Foy,

QC, G1V 4G2, Canada

E-mail: marie-claude.vohl@crchul.ulaval.ca

Tel.: + 1-418-6564141

Fax: + 1-418-6542145

M.-T. Berthier · A.-M. Paradis · M.-C. Vohl Department of Food Science and Nutrition, Laval University, Sainte-Foy, QC, Canada

J.-P. Després

Quebec Heart Institute, QC, Canada

D. Gaudet

Montreal University Community Genomic Medicine Center and Chicoutimi Hospital Lipid Clinic, Chicoutimi Hospital, QC, Canada abdominal visceral AT and plasma LDL-apoB concentrations.

Keywords Microsomal transfer protein · Plasma lipid · Apolipoprotein B · Insulin · Visceral obesity ·

Dyslipidemia $\cdot$ Polymorphism

\section{Introduction}

The assembly of apolipoprotein B (apoB) containing lipoproteins is a complex process in which the microsomal triglyceride transfer protein (MTP) plays an important role. MTP is expressed at high levels in the lumen of endoplasmic reticulum of enterocytes and hepatocytes (Wetterau et al. 1992; Nielsen et al. 1998) and at relatively low levels in the kidney and in cardiac muscle (Boren et al. 1998; Raabe et al. 1998). The protein disulfide isomerase (PDI) and a larger subunit of $97 \mathrm{kDa}$, responsible for the lipid transfer activity compose the heterodimer of MTP. The interaction between these two subunits seems to be irreversible (Wetterau et al. 1990, 1991). MTP catalyses the assembly of triglyceride-rich plasma lipoproteins (VLDL) and chylomicrons by carrying lipid from endoplasmic reticulum membrane to apoB particles in the lumen of endoplasmic reticulum (Olofsson et al. 1999). The assembly of lipoproteins involves a physical binding of apoB and the larger subunit of MTP, but the precise mechanism remains to be elucidated (Bradbury et al. 1999; Gretch et al. 1996; Liang and Ginsberg 2001; Wetterau et al. 1990).

Because MTP plays a critical role in the assembly of apoB-containing lipoproteins, some variants of its gene may have an impact on plasma lipoprotein levels and related atherosclerosis risk. One study reported that Q94H, I128T, and H297Q coding single nucleotide polymorphisms were associated with variations in plasma total and LDL cholesterol levels, as well as with variations in apoB concentrations and in body mass 
index (BMI) (Ledmyr et al. 2002). Several studies were performed on MTP promoter polymorphisms, mainly with $-493 \mathrm{G}>\mathrm{T},-400 \mathrm{~A}>\mathrm{T}$, and $-164 \mathrm{~T}>\mathrm{C}$. Although these polymorphisms had not been found to be associated with plasma lipoprotein-lipid levels in the Caucasian population of the ECTIM study (Herrmann et al. 1998) or in the Framingham Offspring study (Couture et al. 2000), the polymorphism $-493 \mathrm{G}>\mathrm{T}$ was reported to be associated with higher levels of apoB-related lipids in a cohort of permanent residents of the Stockholm metropolitan area (Karpe et al. 1998; Ledmyr et al. 2002) and in young African American men (Hank Juo et al. 1998). In French Canadian men, visceral obesity was found to influence the relationship between the $-493 \mathrm{G}>\mathrm{T}$ polymorphism and $\mathrm{LDL}-\mathrm{apoB}$ or $\mathrm{LDL}$ peak particle diameter (St. Pierre et al. 2002).

The objectives of this study were first to verify the association between MTP gene polymorphisms and both anthropometric and plasma lipoprotein variables and then to determine whether these associations varied as a function of visceral obesity.

\section{Methods}

\section{Subjects}

The MTP gene was first sequenced in seven individuals exhibiting low apoB concentrations $(<1.09 \mathrm{~g} / \mathrm{l})$ and nine subjects with high apoB concentrations $(\geq 1.09 \mathrm{~g} / \mathrm{l})$. When a polymorphism was found, a sample of 270 unrelated men recruited from the greater Quebec City area and selected to cover a wide range of body fatness values was genotyped. These men were all nonsmokers and free from metabolic disorders, such as arterial hypertension, type 2 diabetes, and coronary heart disease. None of them was using medications known to affect insulin action or plasma lipoprotein/lipid levels. The range of total apoB concentrations in this cohort varied from 0.36 to $1.63 \mathrm{~g} / \mathrm{l}$, with a median value at $1.09 \mathrm{~g} / 1$. All subjects gave their written consent to participate into this study, which was approved by the ethics committee of Laval University.

\section{Anthropometric measurements}

Waist circumference, body weight, and height were measured following standardized procedures (Van der kooy and Seidell 1993). Visceral adipose tissue (AT) area at the $\mathrm{L}_{4} \mathrm{~L}_{5}$ level was measured by computed tomography on a Siemens Somatom DRH scanner (Erlagen, Germany), as previously described (Després et al. 1991; Ferland et al. 1989).

\section{Lipoprotein and lipid measurements}

ApoB concentrations were measured in plasma and infranatant (LDL-apoB; $d>1.006 \mathrm{~g} / \mathrm{ml}$ ) by the rocket immunoelectrophoretic method of Laurell (Laurell 1966), as previously described (Krasinski et al. 1990). Serum standards were prepared in our laboratory and calibrated against reference sera obtained from the Centre for Disease Control (Atlanta, GA, USA), which had been lyophilized and stored at $-80^{\circ} \mathrm{C}$ until use (Ruotolo et al. 1992).

\section{PCR amplification and sequencing of MTP}

In order to design intronic primers for the amplification of each exon, genomic sequences were sought for the intronic regions surrounding all MTP exons. To do so, we compared mRNA sequences of each exons of MTP found in the nucleotides site (http://www.ncbi.nlm.nih.gov/entrez/query.fcgi/nucleotide) with a genomic DNA sequence (accession number: gi:18098543). Intronic primers were designed using the Primer 3.0 software (http://wwwgenome.wi.mit.edu/cgibin/primer/primer3.cgi), as previously described (Berthier et al. 2004).

Genomic DNA was isolated from white blood cells with a Sigma kit (GenElute Blood Genomic DNA Kit Miniprep, Sigma). The promoter region and the 18 exons were amplified from genomic DNA by the use of specific primers, with the adequate annealing temperature (Berthier et al., 2004). PCR reaction volume was $50 \mu \mathrm{l}$, and conditions were as follows: $1.25 \mathrm{U}$ AmpliTaqDNA polymerase (Perkin-Elmer Cetus) in the buffer recommended by the manufacturer, $1.5 \mathrm{mM}$ of $\mathrm{MgCl}_{2}$, $0.2 \mathrm{mM}$ dNTPs, primers at final concentration of $0.8 \mu \mathrm{M}$, and $100 \mathrm{ng}$ of genomic DNA. PCR products were purified by QIAQuick8 PCR purification kit (Qiagen Inc., Mississauga, ON, Canada). Sequencing reaction were performed using a BigDye Terminator v3.0 cycle sequencing (ABI Prism, Applied biosystem, Foster city, CA, USA), and the products were analyzed on an ABI 3100 automated DNA sequencer (PE Applied Biosystems, Foster City, CA, USA). The gel files were processed using the ABI Prism 3100 data collection software Applied Biosystem version 1.1 and ABI Prism DNA sequencing analysis software (PE Applied Biosystems) then assembled and analyzed using the STADEN preGap4 and Gap4 programs.

\section{Detection of sequence variations}

A PCR-RFLP-based method was used to genotype sequence variations in the larger cohort of 270 unrelated men. The corresponding restriction enzyme was chosen, as previously described (Berthier et al. 2004). Digestion products were size-separated on $8 \%$ polyacrylamide gel (for c. $383 \mathrm{~T}>\mathrm{C}$, c. $891 \mathrm{C}>\mathrm{G}$, c. $2884 \mathrm{G}>\mathrm{C}$, c. $-400 \mathrm{~A}>\mathrm{T}$, c. $-164 \mathrm{~T}>\mathrm{C}$ polymorphisms), $20 \%$ polyacrylamide electrophoresis gel (c. $-493 \mathrm{G}>\mathrm{T}$ polymorphism), or $4 \%$ agarose gel $\quad$ (c. $282 \mathrm{G}>\mathrm{C}, \quad$ c. $453 \mathrm{~T}>\mathrm{C}, \quad$ c. $933 \mathrm{C}>\mathrm{A}$, c. $969 \mathrm{~T}>\mathrm{C}$, c. $1151 \mathrm{~A}>\mathrm{C}$ polymorphisms) according to 
differences in fragment sizes, subsequently stained with ethidium bromide, and pictured on a UV light box.

Linkage disequilibrium coefficient of polymorphism sites of MTP genes

To establish possible linkage disequilibrium between two polymorphisms, we used two softwares-EH and 2LD. Possible haplotypes were created using PM software. $\mathrm{EH}, 2 \mathrm{LD}$, and PM were found at the site http:// www.hgmp.mrc.ac.uk.

\section{Statistical analyses}

After dividing the sample according to noncarriers and carriers of mutation, comparisons were performed using Student's $t$ test. Analysis of covariance was also performed to adjust variables for age or age and visceral $\mathrm{AT}$, and the LSMEANS procedure was used to detect significant differences between groups. The gene-counting method with a chi-squared test was used to compare the frequencies between created haplotypes described in Table 2, and groups were divided by either waist girth, visceral AT, or total apoB and LDL-apoB concentrations. The cutoff points of $100 \mathrm{~cm}, 130 \mathrm{~cm}^{2}$, and $1.09 \mathrm{~g} / 1$ were used, respectively, for waist girth, visceral AT accumulation (Pouliot et al. 1994), and total apoB levels (Connelly et al. 1999). The median value of $0.9 \mathrm{~g} / 1$ was chosen as the cutoff point for LDL-apoB.

To study how visceral obesity could modify the effect of a genotype on the lipoprotein/lipid profile, genotype groups were further classified on the basis of their amount of visceral AT. The value of $130 \mathrm{~cm}^{2}$ for visceral AT was used to identify subjects with low versus elevated visceral AT accumulation. As previously reported by Després et al., men with visceral AT accumulation greater than this value are at increased risk of being characterized by a cluster of metabolic abnormalities predictive of cardiovascular disease risk (Després and Lamarche 1993). Comparisons among subgroups were performed using an ANOVA in order to quantify the effect of visceral AT in the various genotype groups. The

Fig. 1 cDNA of the microsomal triglyceride transfer protein (MTP) gene with observed sequence variations by direct sequencing and frequencies of each mutation in French Canadians. $D^{\prime}$ linkage disequilibrium coefficient, $P P$ value, underlined polymorphisms were newly discovered
Duncan multiple-range comparison test was used in cases where a significant group effect was noted. Analyses of covariance were also performed to adjust variables for age, and differences between groups were identified with the LSMEANS procedure. These statistical analyses were conducted with the SAS statistical package (SAS Inst., Cary, NC, USA), and a value of $P<0.05$ was considered significant.

\section{Results}

Coding regions, exon-intron splicing boundaries, and $5^{\prime}$ and $3^{\prime}$ regions of the MTP gene were sequenced in seven individuals with low apoB $(<1.09 \mathrm{~g} / \mathrm{l})$ concentrations and nine subjects with high apoB concentrations $(\geq 1.09 \mathrm{~g} / \mathrm{l})$. Eleven polymorphisms were identified, and three of them, c.933C $>\mathrm{A}, \quad$ c. $969 \mathrm{~T}>\mathrm{C}, \quad$ and c. $2884 \mathrm{G}>\mathrm{C}$, were newly discovered (Berthier et al. 2004) (Fig. 1). Association studies were not pursued further for the c. $2884 \mathrm{G}>\mathrm{C}$ since it does not alter the amino acid sequence.

Association of MTP gene polymorphisms with obesity-related phenotypes

The associations between each polymorphism and indices of obesity examined in the present study are shown in Table 1. Carriers of 933A or $1151 \mathrm{C}$ alleles as well as $-400 \mathrm{~A} / \mathrm{A}$ homozygotes were more viscerally obese, as reflected by a higher visceral AT area, than their respective counterparts $(P<0.05)$. Differences remained statistically significant after adjustment for age. A higher waist circumference was also observed among $-400 \mathrm{~A} / \mathrm{A}$ homozygotes compared with $-400 \mathrm{~T}$ carriers (Table 1).

No impact of the c. $969 \mathrm{~T}>\mathrm{C}$ was observed on anthropometric indices and plasma apoB levels. No significant association between MTP gene polymorphisms and plasma triglyceride concentrations was found after adjustment for age and visceral obesity (data not shown).

Influence of visceral AT on the relationship between MTP polymorphisms and plasma lipoprotein/lipid levels

We also examined whether visceral obesity could modulate the association between some polymorphisms and plasma lipoprotein/lipid levels. For that purpose, each genotype group was divided into two subgroups with

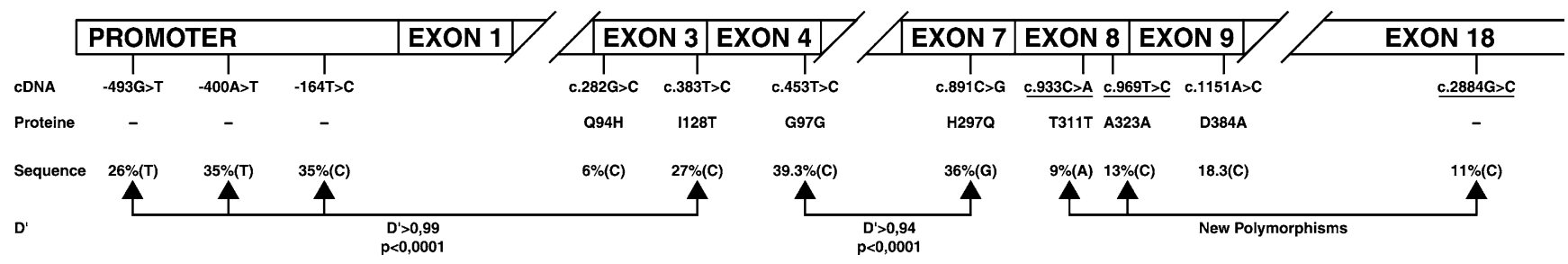


Table 1 Comparison of obesity indices and plasma apolipoprotein B (apoB) levels between microsomal triglyceride transfer protein (MTP) genotype groups. Number of subjects is shown in parentheses. 1 homozygotes for normal allele, 2 carriers of mutated allele

\begin{tabular}{|c|c|c|c|c|c|}
\hline & $-400 \mathrm{~A}>\mathrm{T}$ & c. $282 \mathrm{G}>\mathrm{C}$ & c. $891 \mathrm{C}>\mathrm{G}$ & c. $933 \mathrm{C}>\mathrm{A}$ & c. $1151 \mathrm{~A}>\mathrm{C}$ \\
\hline \multicolumn{6}{|c|}{ Visceral adipose tissue $\left(\mathrm{cm}^{2}\right)$} \\
\hline 1 & $168.79 \pm 51.80(105)$ & $163.13 \pm 54.88$ & $163.68 \pm 55.13(100)$ & $156.82 \pm 56.30(215)$ & $157.52 \pm 57.46(197)$ \\
\hline$P^{*}$ & 0.005 & 0.78 & 0.17 & 0.02 & 0.03 \\
\hline \multicolumn{6}{|c|}{ Waist circumference $(\mathrm{cm})$} \\
\hline 1 & $102.83 \pm 10.64(105)$ & $100.8 \pm 10.96(203)$ & $101.01 \pm 11.35(102)$ & $100.41 \pm 11.10$ & $100.41 \pm 11.52$ \\
\hline 2 & $99.64 \pm 10.71(153)$ & $103.41 \pm 11.32$ & $100.45 \pm 10.88(169)$ & $103.29 \pm 1082(49)$ & $101.38 \pm 9.60(77)$ \\
\hline 1 & $1.07 \pm 0.23(98)$ & $1.09 \pm 0.21(190)$ & $1.10 \pm 0.21(101)$ & $1.04 \pm 0.22(205)$ & $1.08 \pm 0.22(188)$ \\
\hline 2 & $1.08 \pm 0.22(145)$ & $1.06 \pm 0.20(27)$ & $1.06 \pm 0.22(158)$ & $1.08 \pm 0.21(46)$ & $1.06 \pm 0.22(70)$ \\
\hline$P^{*}$ & 0.81 & 0.74 & 0.08 & 0.86 & 0.84 \\
\hline$P^{* *}$ & 0.63 & 0.61 & 0.16 & 0.38 & 0.57 \\
\hline \multicolumn{6}{|c|}{ LDL-apoB (g/l) } \\
\hline 1 & $0.93 \pm 0.20(98)$ & $0.96 \pm 0.19(190)$ & $0.97 \pm 0.17(101)$ & $0.94 \pm 0.19(205)$ & $0.94 \pm 0.19(186)$ \\
\hline
\end{tabular}

$* P P$ value adjusted for age

**P $P$ value adjusted for age and visceral adipose tissue (AT)

either low or high levels of visceral AT using a cutoff point of $130 \mathrm{~cm}^{2}$ (Fig. 2). Significantly elevated LDLapoB concentrations were found in viscerally obese $-400 \mathrm{~T}$ carriers $(P=0.006), 282 \mathrm{G} / \mathrm{G}$ homozygotes $(P=0.03), 891 \mathrm{G}$ carriers $(P=0.01), 933 \mathrm{C} / \mathrm{C}$ homozygotes $(P=0.01)$, and $1151 \mathrm{~A} / \mathrm{A}$ homozygotes $(P=0.02)$ compared to lean subjects with the same corresponding genotype (Fig. 2a,b). Thus, carriers of the $-400 \mathrm{~T}$ allele, the $891 \mathrm{G}$ allele, $282 \mathrm{G} / \mathrm{G}$ homozygotes, $933 \mathrm{C} / \mathrm{C}$ homozygotes, and $1151 \mathrm{~A} / \mathrm{A}$ homozygotes were more sensitive to visceral obesity than their respective counterparts. Consequently, Fig. 2 illustrates a possible gene/visceral obesity interaction on plasma apoB concentrations.

Five haplotypes were constructed with polymorphisms $-493 \mathrm{G}>\mathrm{T}, \quad-400 \mathrm{~A}>\mathrm{T}, \quad-164 \mathrm{~T}>\mathrm{C}$, and c. $383 \mathrm{~T}>\mathrm{C}$ and four with polymorphisms c.453 $\mathrm{T}>\mathrm{C}$ and c. $891 \mathrm{C}>\mathrm{G}$. The frequencies of each haplotype are presented in Table 2. To assess the contribution of each haplotype to the presence of abdominal obesity and lipoprotein-lipid perturbations, we compared each haplotype frequency of that variants in subgroups divided on the basis of visceral AT accumulation on waist circumference using cutoff points of $130 \mathrm{~cm}^{2}$ or $100 \mathrm{~cm}$, respectively (not shown). No significant difference was observed when the study sample was subdivided into subgroups on the basis of total and LDL-apoB levels (not shown).

\section{Discussion}

Most MTP gene polymorphisms were discovered during mutational screening of abetalipoproteinemia (Narcisi et al. 1995; Rehberg et al. 1996). However, few studies were interested at the effects of these polymorphisms on lipoprotein/lipid levels of subjects not characterized by abetalipoproteinemia. The objective of the present study was to study the impact of different MTP polymorphisms on indices of adiposity and plasma lipoprotein/ lipid levels. We also wanted to verify whether the amount of visceral AT may modulate the association between MTP gene polymorphisms and plasma lipoprotein/lipid levels.

The frequency of the different polymorphisms found within our study sample of French Canadian men was similar to the one reported in other Caucasian populations [c. $282 \mathrm{G}>\mathrm{C}, \quad$ c.383 $\mathrm{T}>\mathrm{C}$ (Ledmyr et al. 2002; Narcisi et al. 1995), $-493 \mathrm{G}>\mathrm{T}$ (Couture et al. 2000; Juo et al. 2000; Karpe et al. 1998; Ledmyr et al. 2002), $-400 \mathrm{~A}>\mathrm{T}$ (Herrmann et al. 1998; Karpe et al. 1998)] while it was slightly higher than what has been previously observed in a population from northern Europe $[-164 \mathrm{~T}>\mathrm{C},-400 \mathrm{~A}>\mathrm{T}$ and c.891C $>\mathrm{G}$ (Ledmyr et al. 2002)]. Discrepancies in allele frequencies as well as the absence of the reported Q244E polymorphism (Ledmyr et al. 2002) in our sample of French Canadian men is likely to be attributable to differences in population origin and to the presence of different ancestors between the Swedish and the French Canadian populations.

The $-400 \mathrm{~A}>\mathrm{T}$ polymorphism was associated with visceral AT accumulation and waist circumference (Table 1). The $-400 \mathrm{~A} / \mathrm{A}$ homozygotes were more obese than carriers of the $-400 \mathrm{~T}$ allele. In contrast, Ledmyr et al. observed significantly higher BMI and waist circumference values in carriers of the $-400 \mathrm{~T}$ allele in a sample of healthy men from the Stockholm area. In their study, the sample of men was divided into three genotype groups, and differences between those homozygous for the $-400 \mathrm{~A}>\mathrm{T}$ mutation and carriers of $-400 \mathrm{~A}$ allele were observed (Ledmyr et al. 2002). Such differences in the analytical approaches used may explain discrepancies between their results and ours. In viscerally obese rats (OLETF rats) at 6 weeks, before the development of insulin resistance, a significant increase of MTP mRNA 

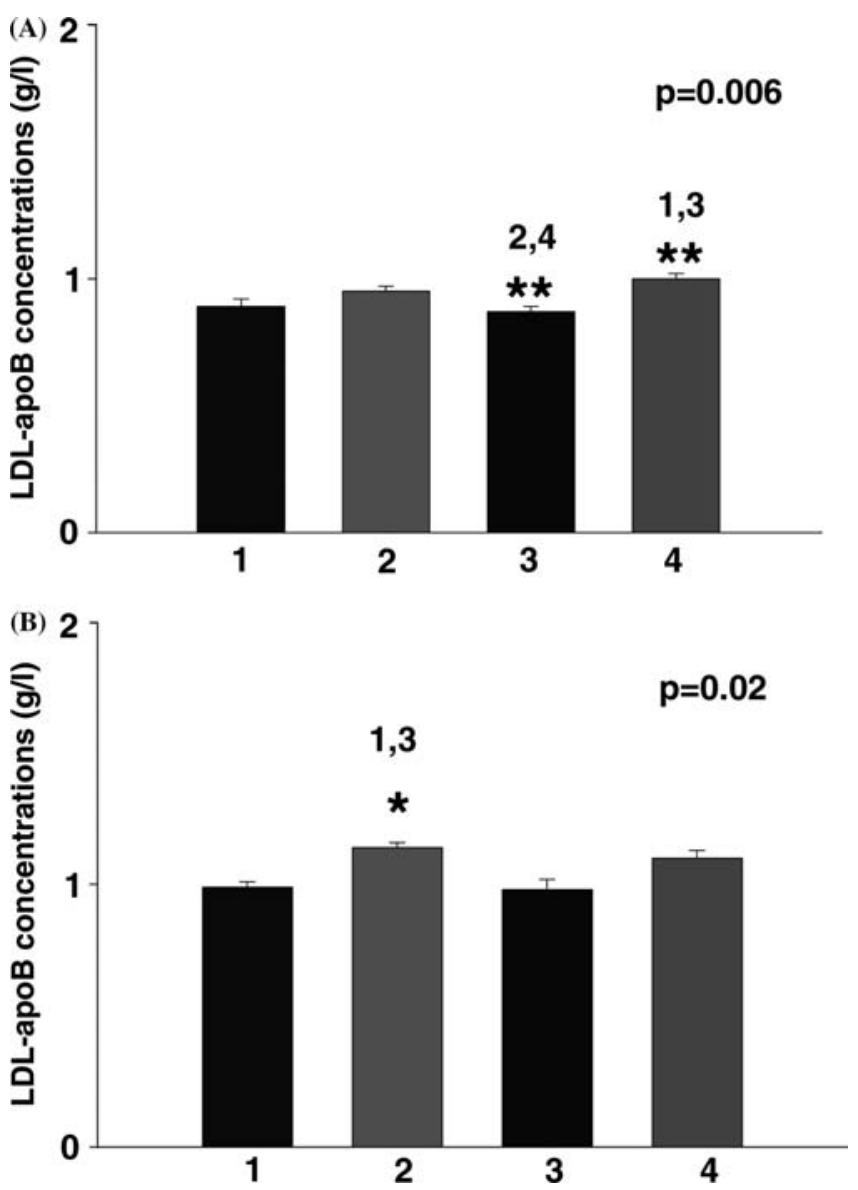

Fig. 2 a Plasma low-density lipoprotein (LDL)-apolipoprotein B (apoB) levels in the $-400 \mathrm{~A}>\mathrm{T}$ microsomal triglyceride transfer protein (MTP) genotype classified as a function of visceral adipose tissue (AT) (low versus high) using $130 \mathrm{~cm}^{2}$ as the cutoff point for visceral AT. Bar graphs comparing LDL and apoB concentration within each genotype in men with low $\left(<130 \mathrm{~cm}^{2}\right)$ or high $\left(\geq 130 \mathrm{~cm}^{2}\right)$ visceral AT after adjustment for age. The number below each bar identifies the subgroups: 1 homozygotes for normal allele with visceral AT<130 $\mathrm{cm}^{2}(n=33), 2$ homozygotes for normal allele with visceral AT $\geq 130 \mathrm{~cm}^{2}(n=65), 3$ carriers of mutation with visceral AT $<130 \mathrm{~cm}^{2} \quad(n=51), 4$ carriers of mutation with visceral AT $\geq 130 \mathrm{~cm}^{2}(n=94)$. The number above each bar indicates groups that differ significantly. $P$ value was adjusted for age. Similar results were also found for $891 \mathrm{C}>\mathrm{G}$ polymorphism. b Plasma LDL-apoB levels in the $1151 \mathrm{~A}>\mathrm{C}$ MTP genotype classified as a function of visceral AT (low versus high) using $130 \mathrm{~cm}^{2}$ as the cutoff point for visceral AT. Bar graphs comparing the LDL and apoB concentration within each genotype in men with low $\left(<130 \mathrm{~cm}^{2}\right)$ or high $\left(\geq 130 \mathrm{~cm}^{2}\right)$ visceral AT after adjustment for age. The number below each bar identifies the subgroups: 1 1151A/A homozygotes and visceral AT $<130 \mathrm{~cm}^{2}$ $(n=68), 21151 \mathrm{~A} / \mathrm{A}$ homozygotes and visceral AT $\geq 130 \mathrm{~cm}^{2}$ $(n=118), 31151 \mathrm{C}$ allele carriers and visceral AT $<130 \mathrm{~cm}^{2}$ $(n=21), 41151 \mathrm{C}$ allele carriers and visceral AT $\geq 130 \mathrm{~cm}^{2}(n=51)$. Numbers above the bars indicate groups that differ significantly. $P$ value was adjusted for age. Similar results were also found for 282 $\mathrm{G}>\mathrm{C}(P=0.03)$ and $933 \mathrm{C}>\mathrm{A}(P=0.01)$ polymorphisms

levels was observed whereas apoB mRNA levels were similar to those observed in normal rats (LETO rats) (Kuriyama et al. 1998). In viscerally obese men, the $-493 \mathrm{G}>\mathrm{T}$ polymorphism has been associated with CETP gene expression, but the precise mechanism
Table 2 Haplotype frequency. $H 1$ haplotypes created with polymorphisms $-493 \mathrm{G}>\mathrm{T},-400 \mathrm{~A}>\mathrm{T},-164 \mathrm{~T}>\mathrm{C}$ and $383 \mathrm{~T}>\mathrm{C} ; \mathrm{H} 2$ haplotype created with polymorphisms $453 \mathrm{~T}>\mathrm{C}$ and $891 \mathrm{C}>\mathrm{G}$

\begin{tabular}{|c|c|c|}
\hline Haplotype & Haplotype sequence & $\begin{array}{l}\text { Haplotype } \\
\text { frequency }(\%)\end{array}$ \\
\hline
\end{tabular}

\begin{tabular}{llr}
\hline $\mathrm{H} 1$ & & \\
$H 1 a$ & $-493 \mathrm{G} /-400 \mathrm{~A} /-164 \mathrm{~T} / 383 \mathrm{C}$ & 0.2 \\
$H 1 b$ & $-493 \mathrm{G} /-400 \mathrm{~A} /-164 \mathrm{~T} / 383 \mathrm{~T}$ & 63.3 \\
$H 1 c$ & $-493 \mathrm{G} /-400 \mathrm{~T} /-164 \mathrm{~T} / 383 \mathrm{~T}$ & 9.7 \\
H1d & $-493 \mathrm{~T} /-400 \mathrm{~T} /-164 \mathrm{C} / 383 \mathrm{C}$ & 26.4 \\
H1e & $-493 \mathrm{~T} /-400 \mathrm{~T} /-164 \mathrm{C} / 383 \mathrm{~T}$ & 0.4 \\
$\mathrm{H} 2$ & & \\
$H 2 a$ & $453 \mathrm{~T} / 891 \mathrm{C}$ & 58.7 \\
$H 2 b$ & $453 \mathrm{~T} / 891 \mathrm{G}$ & 1.6 \\
$H 2 c$ & $453 \mathrm{C} / 891 \mathrm{C}$ & 5.5 \\
$H 2 d$ & $453 \mathrm{C} / 891 \mathrm{G}$ & 34.2 \\
\hline
\end{tabular}

whereby CETP regulates apoB is unclear. Moreover, the $-493 \mathrm{G}>\mathrm{T}$ polymorphism was also associated with an elevated expression of the MTP protein in obese men (Watts et al. 2000). Consequently, a default in the expression of MTP could be related to visceral obesity. This default may be the consequence of mutations in this gene or in a gene in linkage disequilibrium with it. No effect on metabolic profile or on anthropometric indices were observed for $-493 \mathrm{G}>\mathrm{T}, \quad-164 \mathrm{~T}>\mathrm{C}$, and c. $383 \mathrm{~T}>\mathrm{C}$. The $-493 \mathrm{G}>\mathrm{T}$ polymorphism has been predominantly studied, but results in Caucasian populations remain controversial. Indeed, some authors reported an association between $-493 \mathrm{G}>\mathrm{T}$ and adiposity as well as between this genotype and LDL particle size (Ledmyr et al. 2002; Juo et al. 2000). This polymorphism may also be associated with an increased risk of cardiovascular disease without being related to plasma lipoprotein/lipid levels (Ledmyr et al. 2004). However, Couture et al. found no difference in plasma lipid levels or adiposity indices between carriers and noncarriers of the mutation in the Framingham Offspring study (Couture et al. 2000). This discrepancy in the results may be explained by the impact of different environmental factors, which could modulate the effect of mutation itself. The fact that the $-493 \mathrm{G}>\mathrm{T}$ polymorphism may simply reflect the effect of another polymorphism has not yet been excluded. Moreover, after dividing the two c. $891 \mathrm{G}>\mathrm{C}$ genotype groups into subgroups based on the amount of visceral AT, similar results to what were found for $-400 \mathrm{~A}>\mathrm{T}$ polymorphism was observed on plasma LDL-apoB levels (Fig. $2 \mathrm{a}, P=0.01$ ). As a consequence, the simultaneous presence of visceral obesity and this genotype may also affect atherosclerotic risk by modulating plasma LDL-apoB concentrations.

Polymorphisms $-493 \mathrm{G}>\mathrm{T},-400 \mathrm{~A}>\mathrm{T},-164 \mathrm{~T}>\mathrm{C}$, and c.383 T $>\mathrm{C}$ were in linkage disequilibrium $\left(D^{\prime} \geq 0.99\right.$, $P<0.0001$, Table 2). Ledmyr et al. also showed linkage disequilibrium between $-493 \mathrm{G}>\mathrm{T},-164 \mathrm{~T}>\mathrm{C}$, and c. $383 \mathrm{~T}>\mathrm{C}$ as well as between $-400 \mathrm{~A}>\mathrm{T}$ and $-493 \mathrm{G}>\mathrm{T}$ (Ledmyr et al. 2002). Haplotypes built (Table 1) with sequence variations in linkage disequilibrium with $-400 \mathrm{~A}>\mathrm{T}$ polymorphism were not associated with 
abdominal adiposity or plasma apoB concentrations. These results suggest that these combinations of genetic variations may not play a major role in the etiology of abdominal obesity, and the polymorphism $-400 \mathrm{~A}>\mathrm{T}$ may be in linkage disequilibrium with a polymorphism in another gene that may have a metabolic impact. However, use of more sophisticated software and study of a larger cohort would be necessary to verify this hypothesis. Another haplotype created with c. $453 \mathrm{~T}>\mathrm{C}$ and c. $891 \mathrm{C}>\mathrm{G}$ (Table 2) also did not have any association with metabolic profile. This lack of effect may be explained by the low number of subjects and, again, these results warrant replications in larger study samples.

No impact of c. $282 \mathrm{G}>\mathrm{C}$ genotype upon anthropometric measurements was found, which is in agreement with data of Ledmyr et al. (2002). However, two polymorphisms, c. $933 \mathrm{C}>\mathrm{A}$ and c.1151A $>\mathrm{C}$, were observed to be directly associated with visceral AT (Table 1). In our opinion, because this study is the first to verify the effect of c. $933 \mathrm{C}>\mathrm{A}$ and c.1151 $\mathrm{A}>\mathrm{C}$ polymorphisms, these results warrant replications. Then, after dividing each genotype group into subgroups according to the presence or the absence of visceral obesity, LDL-apoB levels were higher in viscerally obese $282 \mathrm{G} / \mathrm{G}$ homozygotes, 933C/C homozygotes, and 1151A/A homozygotes than in lean respective counterparts whereas similar LDL-apoB levels were found among lean and viscerally obese $282 \mathrm{C}$ carriers $(P=0.03), 933 \mathrm{~A}$ carriers $(P=0.01)$, and $1151 \mathrm{C}$ carriers $(P=0.02)$. Data from the present study suggest that the presence of visceral obesity may exacerbate the $282 \mathrm{G}$ allele, $933 \mathrm{C}$ allele, and $1151 \mathrm{~A}$ allele on LDL-apoB levels. Elevated apoB levels is considered as a significant risk factor for cardiovascular disease (Lamarche et al. 1998). Therefore, the $282 \mathrm{G}$ allele, $933 \mathrm{C}$ allele, and 1151A could be more deleterious than the 282C allele, 933A allele, and 1151C allele. However, because of the rather limited number of subjects upon which these results are based, this study warrants confirmation in an independent study sample. Some other studies in larger cohorts must confirm this impact.

It is unclear how a silent polymorphism such as c. $933 \mathrm{C}>\mathrm{A}$ could have the observed impact on adiposity and lipoprotein/lipid concentrations. This polymorphism may be in linkage disequilibrium with polymorphisms in introns that would destabilize premRNA and would result in reduced mRNA levels (Stumvoll et al. 2002), or it could be in linkage disequilibrium with a neighboring gene influencing plasma lipoprotein lipid levels.

In conclusion, some MTP polymorphisms were found to have a direct association with indices of adiposity. The magnitude of the associations between plasma LDL and apoB levels and variations in the MTP gene could also be modulated by the presence of visceral AT accumulation.

Acknowledgements We are indebted to the subjects involved in this study. We want to acknowledge Alya'a Sammak and Andrei Verner from Genome Quebec Innovation Centre at McGill University
(Montréal, Québec, Canada) for their technical support. MarieClaude Vohl and Patrick Couture are recipients, respectively, of a research and a clinical scholarship from the Fonds de la Recherche en Santé du Québec (FRSQ). Daniel Gaudet is the chairholder of the Canada Research Chair in preventive genetics and community genomics (http://www.chairs.gc.ca). Jean-Pierre Després is chair professor of Human Nutrition, Lipidology and Prevention of Cardiovascular Disease supported by Pfizer Canada and Provigo. Marie-Thérèse Berthier is a recipient of a studentship from the chair of Human Nutrition, Lipidology and Prevention of Cardiovascular Disease supported by Pfizer Canada and Provigo. This work was supported by the Canadian Institutes for Health Research (Operating Grant: MOP 44074) and the Heart and Stroke Foundation of Canada.

\section{References}

Berthier MT, Couture P, Houde A, Paradis AM, Sammak A, Verner A, Depres JP, Gagne C, Gaudet D, Vohl MC (2004) The c.419-420insA in the MTP gene is associated with abetalipoproteinemia among French-Canadians. Mol Genet Metab $81: 140-143$

Boren J, Veniant MM, Young SG (1998) Apo B100-containing lipoproteins are secreted by the heart. J Clin Invest 101:11971202

Bradbury P, Mann CJ, Kochl S, Anderson TA, Chester SA, Hancock JM, Ritchie PJ, Amey J, Harrison GB, Levitt DG, Banaszak LJ, Scott J, Shoulders CC (1999) A common binding site on the microsomal triglyceride transfer protein for apolipoprotein $\mathrm{B}$ and protein disulfide isomerase. $\mathbf{J}$ Biol Chem 274:3159-3164

Connelly PW, Petrasovits A, Stachenko S, MacLean DR, Little JA, Chockalingam A (1999) Prevalence of high plasma triglyceride combined with low HDL-C levels and its association with smoking, hypertension, obesity, diabetes, sedentariness and LDL-C levels in the Canadian population. Canadian Heart Health Surveys Research Group. Can J Cardiol 15:428-433

Couture P, Otvos JD, Cupples LA, Wilson PW, Schaefer EJ, Ordovas JM (2000) Absence of association between genetic variation in the promoter of the microsomal triglyceride transfer protein gene and plasma lipoproteins in the Framingham Offspring Study. Atherosclerosis 148:337-343

Després JP, Lamarche B (1993) Effects of diet and physical activity on adiposity and body fat distribution: implications for the prevention of cardiovascular disease. Nutr Res Rev 6:137159

Després JP, Prud'homme D, Pouliot MC, Tremblay A, Bouchard C (1991) Estimation of deep abdominal adipose-tissue accumulation from simple anthropometric measurements in men. Am J Clin Nutr 54:471-477

Ferland M, Després JP, Tremblay A, Pinault S, Nadeau A, Moorjani S, Lupien PJ, Thériault G, Bouchard C (1989) Assessment of adipose tissue distribution by computed axial tomography in obese women: association with body density and anthropometric measurements. Br J Nutr 61:139-148

Gretch DG, Sturley SL, Wang L, Lipton BA, Dunning A, Grunwald KA, Wetterau JR, Yao Z, Talmud P, Attie AD (1996) The amino terminus of apolipoprotein $\mathrm{B}$ is necessary but not sufficient for microsomal triglyceride transfer protein responsiveness. J Biol Chem 271:8682-8691

Hank Juo SH, Bredie SJH, Kiemeney LA, Demacker PNM, Stamler J (1998) A common genetic mechanism determines plasma apolipoprotein B levels and dense LDL subfraction distribution in familial combined hyperlipidemia. Am J Hum Genet 63:586-594

Herrmann SM, Poirier O, Nicaud V, Evans A, Ruidavets JB, Luc G, Arveiler D, Bao-Sheng C, Cambien F (1998) Identification of two polymorphisms in the promoter of the microsomal triglyceride transfer protein (MTP) gene: lack of association with lipoprotein profiles. J Lipid Res 39:2432-2435 
Juo SH, Han Z, Smith JD, Colangelo L, Liu K (2000) Common polymorphism in promoter of microsomal triglyceride transfer protein gene influences cholesterol, ApoB, and triglyceride levels in young african american men: results from the coronary artery risk development in young adults (CARDIA) study. Arterioscler Thromb Vasc Biol 20:1316-1322

Karpe F, Lundahl B, Ehrenborg E, Eriksson P, Hamsten A (1998) A common functional polymorphism in the promoter region of the microsomal triglyceride transfer protein gene influences plasma LDL levels. Arterioscler Thromb Vasc Biol 18:756-761

Krasinski SD, Cohn JS, Russell RM, Schaefer EJ (1990) Postprandial plasma vitamin A metabolism in humans: a reassessment of the use of plasma retinyl esters as markers for intestinally derived chylomicrons and their remnants. Metabolism 39:357-365

Kuriyama H, Yamashita S, Shimomura I, Funahashi T, Ishigami M, Aragane K, Miyaoka K, Nakamura T, Takemura K, Man Z, Toide K, Nakayama N, Fukuda Y, Lin MC, Wetterau JR, Matsuzawa Y (1998) Enhanced expression of hepatic acylcoenzyme A synthetase and microsomal triglyceride transfer protein messenger RNAs in the obese and hypertriglyceridemic rat with visceral fat accumulation. Hepatology 27:557-562

Lamarche B, Tchernof A, Mauriege P, Cantin B, Dagenais GR, Lupien PJ, Despres JP (1998) Fasting insulin and apolipoprotein B levels and low-density lipoprotein particle size as risk factors for ischemic heart disease. JAMA 279:1955-1961

Laurell CB (1966) Quantitative estimation of proteins by electrophoresis in agarose gel containing antibodies. Anal Biochem 15:42

Ledmyr H, Karpe F, Lundahl B, McKinnon M, Skoglund-Andersson C, Ehrenborg E (2002) Variants of the microsomal triglyceride transfer protein gene are associated with plasma cholesterol levels and body mass index. J Lipid Res 43:51-58

Ledmyr H, McMahon AD, Ehrenborg E, Nielsen LB, Neville M, Lithell H, MacFarlane PW, Packard CJ, Karpe F (2004) The microsomal triglyceride transfer protein gene-493T variant lowers cholesterol but increases the risk of coronary heart disease. Circulation 109:2279-2284

Liang J, Ginsberg HN (2001) Microsomal triglyceride transfer protein binding and lipid transfer activities are independent of each other, but both are required for secretion of apolipoprotein B lipoproteins from liver cells. J Biol Chem 276:2860628612

Narcisi TM, Shoulders CC, Chester SA, Read J, Brett DJ, Harrison GB, Grantham TT, Fox MF, Povey S, de Bruin TW (1995) Mutations of the microsomal triglyceride-transfer-protein gene in abetalipoproteinemia. Am J Hum Genet 57:1298-1310

Nielsen LB, Veniant M, Boren J, Raabe M, Wong JS, Tam C, Flynn L, Vanni-Reyes T, Gunn MD, Goldberg IJ, Hamilton RL, Young SG (1998) Genes for apolipoprotein B and microsomal triglyceride transfer protein are expressed in the heart: evidence that the heart has the capacity to synthesize and secrete lipoproteins. Circulation 98:13-16
Olofsson SO, Asp L, Boren J (1999) The assembly and secretion of apolipoprotein B-containing lipoproteins. Curr Opin Lipidol 10:341-346

Pouliot MC, Després JP, Lemieux S, Moorjani S, Bouchard C, Tremblay A, Nadeau A, Lupien PJ (1994) Waist circumference and abdominal sagittal diameter: best simple anthropometric indexes of abdominal visceral adipose tissue accumulation and related cardiovascular risk in men and women. Am J Cardiol 73:460-468

Raabe M, Flynn LM, Zlot CH, Wong JS, Veniant MM, Hamilton RL, Young SG (1998) Knockout of the abetalipoproteinemia gene in mice: reduced lipoprotein secretion in heterozygotes and embryonic lethality in homozygotes. Proc Natl Acad Sci U S A 95:8686-8691

Rehberg EF, Samson-Bouma ME, Kienzle B, Blinderman L, Jamil H, Wetterau JR, Aggerbeck LP, Gordon DA (1996) A novel abetalipoproteinemia genotype. Identification of a missense mutation in the $97-\mathrm{kDa}$ subunit of the microsomal triglyceride transfer protein that prevents complex formation with protein disulfide isomerase. J Biol Chem 271:29945-29952

Ruotolo G, Zhang H, Bentsianov V, Le NA (1992) Protocol for the study of the metabolism of retinyl esters in plasma lipoproteins during postprandial lipemia. J Lipid Res 33:1541-1549

St-Pierre J, Lemieux I, Miller-Felix I, Prud'homme D, Bergeron J, Gaudet D, Nadeau A, Despres JP, Vohl MC (2002) Visceral obesity and hyperinsulinemia modulate the impact of the microsomal triglyceride transfer protein $-493 \mathrm{G} / \mathrm{T}$ polymorphism on plasma lipoprotein levels in men. Atherosclerosis 160:317-324

Stumvoll M, Tschritter O, Fritsche A, Staiger H, Renn W, Weisser M, Machicao F, Haring H (2002) Association of the T-G polymorphism in adiponectin (exon 2) with obesity and insulin sensitivity: interaction with family history of type 2 diabetes. Diabetes 51:37-41

Van der kooy K, Seidell JC (1993) Techniques for the measurement of visceral fat: a practical guide. Int J Obes Relat Metab Disord 17:187-196

Watts GF, Riches FM, Humphries SE, Talmud PJ, van Bockxmeer FM (2000) Genotypic associations of the hepatic secretion of VLDL apolipoprotein B-100 in obesity. J Lipid Res 41:481-488

Wetterau JR, Combs KA, Spinner SN, Joiner BJ (1990) Protein disulfide isomerase is a component of the microsomal triglyceride transfer protein complex. J Biol Chem 265:9801-9807

Wetterau JR, Combs KA, McLean LR, Spinner SN, Aggerbeck LP (1991) Protein disulfide isomerase appears necessary to maintain the catalytically active structure of the microsomal triglyceride transfer protein. Biochem 30:9728-9735

Wetterau JR, Aggerbeck LP, Bouma ME, Eisenberg C, Munck A, Hermier M, Schmitz J, Gay G, Rader DJ, Gregg RE (1992) Absence of microsomal triglyceride transfer protein in individuals with abetalipoproteinemia. Science 258:999-1001 